\title{
Studi Dramaturgi dalam Presentasi Diri Kelompok Jamaah An-Nadzir Kabupaten Gowa
}

\author{
Arianto \\ Departemen Ilmu Komunikasi \\ Fakultas Ilmu Sosial dan Ilmu Politik Universitas Hasanuddin \\ Jl. Perintis Kemerdekaan KM.10 Kampus UNHAS Tamalanrea Makassar 90245 \\ Telp. (0411) 587032, 582500, 588888; Fax. (0411) 587032, 584024 \\ Email: arianto@unhas.ac.id dan arianto0773@gmail.com
}

\begin{abstract}
The purpose of this study is to understand the behavior of managing the appearance of self-presentation by the Jamaah An-Nadzir group in a dramaturgy approach, including management of the front stage and backstage of Jamaah An-Nadzir in social life in Gowa Regency. Qualitative research methods in the conception of phenomenological perspectives are used aiming to explore the self-experience of research subjects in symbolic interactions and dramaturgy approaches. Participatory observation and in-depth interviews as the main instruments of research data collection. The results of the study found that the appearance of the selfrepresentation of Jamaah An-Nadzir through a dramaturgy approach appeared on the theatrical stage as "actor." The front stage as a public/social domain and preaching activities. To do that, the use of attributes, such as the turban, robe, beard, and hair that is left long blond in the community. The rear stage has a different appearance with the management of impressions on the front stage. Impression management is a way of supporting membership or unity in family, friends, and neighbors in social interaction, displaying a percentage of yourself wearing a T-shirt, 3/4 shorts, and raising a hat. The theater stage in the context of the social environment of close and intimate individuals such as being at home, workplace, and humorous to reduce the routines of group propaganda activities. Implication of the use of attributes in communication as part of efforts to interpret the surrounding environment, individual behavior, and individual interpersonal communication can strengthen relationships.
\end{abstract}

Keywords: Self Presentation, Jamaah An-Nadzir, Dramaturgi Approach

\begin{abstract}
Abstrak
Tujuan penelitian ini untuk menemukan pola perilaku pengeloaan kesan tampilan presentasi diri kelompok Jamaah An-Nadzir dalam suatu pendekatan dramaturgi, meliputi: pengelolaan kesan panggung depan (front stage) dan panggung belakang (back stage) Jamaah An-Nadzir dalam kehidupan sosial di Kabupaten Gowa. Metode penelitian kualitatif dalam konsepsi perspektif fenomenologi digunakan bertujuan untuk menggali pengalaman diri subjek penelitian dalam interaksi simbolik dan pendekatan dramaturgi. Observasi partisipatif dan wawancara mendalam sebagai instrumen utama pengumpulan data penelitian. Hasil penelitian menemukan bahwa tampilan representasi diri Jamaah An-Nadzir melalui pendekatan dramaturgi, tampil dalam panggung teatrikal sebagai "aktor". Panggung depan sebagai ranah publik/sosial dan aktivitas dakwah. Melakukan itu, penggunaan atribut, seperti sorban, jubah, jenggot dan rambut yang dibiarkan pirang panjang di lingkungan masyarakat. Panggung belakang memiliki tampilan berbeda dengan pengelolaan kesan di panggung depan. Pengelolaan kesan merupakan cara mendukung keanggotaan atau kesatuan dalam keluarga, teman dan tetangga dalam suatu interaksi sosial. Tampilan presentase diri mengenakan kaos oblong, celana pendek-3/4, serta mengenaikan topi. Panggung teater dalam konteks lingkungan sosial individu yang akrab dan dekat seperti berada dirumah, tempat kerja, dan humoris untuk mengurangi kerutinan aktivitas gerakan dakwah kelompok. Impilikasi penggunaan atribut dalam komunikasi sebagai bagian upaya interpretasi lingkungan sekitar, perilaku individu, dan komunikasi interpersonal individu mampu memperkuat hubungan.
\end{abstract}

Kata Kunci: Presentasi Diri, Jamaah An-Nadzir, Pendekatan Dramaturgi 


\section{Pendahuluan}

Presentasi diri digambarkan sebagai tampilan diri bagi individu lain. Diri dalam kehidupan sosial terbentuk melalui suatu proses interaksi simbolik yang dapat membentuk konsepsi diri. Proses interaksi simbolik berlangsung dalam tatanan komunikasi interpersonal; tatap muka, dialogis, dan umpan balik. Proses komunikasi intens, membentuk identitas diri sebagai produk interaksi simbolik atau interaksi sosial secara dialektika antara individu, kelompok, dan masyarakat dalam realitas sosial. Dialektika menekankan pada aspek interaksi hubungan dan pertukaran antara simbol, serta interpretasi makna dalam memahami pengalaman sosial.

Interaksi setiap manusia dalam kehidupan sosial selaluberusahamemberikan gambaran terbaik dirinya melalui tampilan aktivitas komunikasi. Aktivitas komunikasi tatap muka baik secara verbal maupun nonverbal dilakukan untuk mengkonstruksi diri dalam wujud pengungkapan dan aktualisasi diri. Proses pengungkapan diri atau gambaran diri individu dikenal dengan istilah presentasi diri (self presentation) dalam menunjukkan identitas diri untuk diterima dalam kelompok dan kehidupan sosialnya. Presentasi diri komunitas Jamaah An-Nadzir dalam kehidupan sosial dan dirinya mampu mencapai kesadaran diri, sehingga mengambil sikap dan perilaku sebagai tampilan diri dalam kehidupan sosialnya. Kehidupan sosial keagamaan Jamaah An-Nadzir, di lingkungan sosial Kabupaten Gowa, Kecamatan Bontomarannu, Kelurahan Romanglompoa, tepatnya di pinggiran Danau Mawang dan Danau Balanglabbua. Bermukim komunitas Jamaah Islam yang hingga kini konsisten dalam kehidupan sosial menghidupkan Sunnah Nabi Muhammad SAW melalui tampilan simbol-simbol lahiriah dikesehariannya (Juliadi, 2016).

Tampilan presentasi diri kelompok Jamaah An-Nadzir merupakan hasil produk proses interaksi simbolik dalam kehidupan sosial. Anggota kelompok Jamaah AnNadzir digambarkan sebagai "diri" individu yang ditampilkan kepada individu lainnya. Mead menjelaskan bahwa "diri" dibentuk melalui proses interaksi dengan individu lainnya. Pembentukan diri dalam proses sosial terjadi dalam beberapa tahap penting, yakni tahap imitasi, bermain (playing), serta tahap pertandingan (gaming). Pada ketiga proses ini dikatakan bahwa diri merupakan bentukan yang bersifat individual dan sosial. Bersifat individual bukan berarti bahwa individu membentuk dirinya sendiri, melainkan individu melakukan peniruan dari simbol yang dikirim oleh individu terdekatnya. Di mulai saat individu, mengetahuidiriindividu dalamkelompoknya memiliki kesamaan dengan dirinya sendiri, tercipta pengalaman individual. Secara sosial dikatakan bahwa individu yang sudah mengetahui dan mengalami objek yang ditemuinya, sudah mulai menyadari mengenai keberadaan dirinya dengan objek lainnya dalam sebuah lingkungan. Artinya sifat sosial dari pembentukan diri merupakan hasil atau produk dari interaksi (Benedictus A.S, 2010: 29-30). 
Pengungkapan perilaku diri dalam situasi sosial anggota kelompok Jamaah AnNadzir dalam kehidupan interaksi sosial, berkelompok dan hidup bersama masyarakat area pinggiran Danau Mawang dan Danau Balanglabbua, Kelurahan Romanglompoa, Kabupaten Gowa, konsisten menghidupkan Sunnah Nabi Muhammad SAW melalui tampilan atribut diri khas simbol-simbol Islamiah. Tujuannya untuk menunjukkan identitas kelompok melalui tampilan presentasi diri dalam usaha memahami diri dalam kelompok dan individu lainnya melalui tampilan pesan simbolik. Berkomunikasi bersama individu lain atau kelompok dengan caranya sendiri untuk mengelola kesan dan perilaku optimal (Juliadi, 2016).

Pendekatan interaksi simbolik berusaha memahami perilaku manusia dari sudut pandang subjek. Interaksi simbolik ini menyarankan bahwa perilaku manusia harus dilihat sebagai proses yang memungkinkan membentuk dan mengatur perilaku dengan mempertimbangkan ekspektasi individu lain yang menjadi mitra interaksi. Keunikan dan dinamika simbol dalam proses interaksi sosial menuntut manusia harus lebih kritis, peka, aktif dan kreatif dalam menginterpretasikan simbol-simbol yang muncul dalam interaksi sosial. Penafsiran yang tepat atas simbol tersebut turut menentukan arah perkembangan manusia dan lingkungannya. Sebaliknya, penafsiran yang keliru atas simbol dapat menjadi petaka bagi hidup manusia dan lingkungannya (Haliemah dan Kertamukti, 2017).

Presentasi diri cenderung dilakukan dengan sengaja dan diinginkan untuk dilihat oleh individu lain. Presentasi diri hadir untuk mengontrol persepsi individu lain (Vohs, et al., 2005). Jamah An-Nadzir mempresentasikan dirinya sengaja dengan kesadaran diri agar dapat menyampaikan kesan positif yang optimal di depan individu lain. Meskipun individu lain bertindak berbeda, sesuai situasi yang berbeda.

Presentasi diri dalam kehidupan sosial dianalogikan panggung teatrikal. Panggung sandiwara untuk mempresentasikan diri dalam dunia sosial. Dramaturgi adalah sebuah pendekatan dasar tentang bagaimana individu tampil di kehidupan dunia sosial. Perspektif pendekatan dramaturgi menurut Goffman, dalam bukunya The Presentation of Everyday Life menjelaskan bahwa dramaturgi adalah sebuah pendekatan dasar tentang bagaimana individu tampil di dunia sosial. Goffman memusatkan perhatiannya pada interaksi tatap muka atau kehadiran bersama (co-presence). Individu dapat menyajikan suatu "pertunjukan" apapun bagi individu lain, namun kesan (impression) yang diperoleh individu banyak terhadap pertunjukan itu bisa berbeda-beda. Individu dapat sangat yakin terhadap pertunjukan yang diperlihatkan kepadanya, tetapi dapat juga bersikap sebaliknya (Santoso, 2012: 47).

Penjelasan ini menganalogikan dunia sosial seperti panggung sandiwara dimana individu-individu menjadi aktor yang memegang peran dalam hubungan sosial sebagai representasi yang patuh pada aturan peran yang dilakoni. Presentasi diri dalam kehidupan sehari-hari layaknnya sebuah pertunjukan yang sering dilakukan 
melibatkan individu lain. Goffman tertarik pada kenyataan penting ini dengan menggunakan istilah "dramaturgi" untuk memahami bahwa dalam interaksi sosial individu dibatasi pada apa yang dapat dikatakan dan lakukan, tergantung pada individu dan konteksnya. Seperti aktor di atas panggung, memainkan pengaturan peran spesifik dan penonton. Penjelasan Jennifer (2014):

He used the term 'dramaturgy' to help his readers understand that in social interactions people are restricted by what they can say and do, depending on the audience and context. Like actors on a stage, they play roles specific to the setting and the audience.

Peran sosial layaknya panggung sandiwara, aktor memiliki kemampuan menampilkan "kesan realitas" agar dapat meyakinkan gambaran (image) yang diberikan kepada individu lain. Asumsi dasar, Goffman adalah bahwa peran yang ditampilkan atau yang diharapkan dalam interaksi antar diri sang aktor mengandung simbol tertentu yang digunakan sebagai standar dari perilaku bersama. Diri sang aktor mengelola penempilan diri sendiri, terlebih pada saat penampilan tidak sesuai dengan standar yang disetujui dalam perilaku atau penampilan yang semestinya, mencoba untuk melindungi identitasnya tersebut dengan cara mengelola penampilan dirinya (Umiarso, 2014: 253-254).

Perspektif pendekatan dramaturgi, ibarat "panggung teater", tampilan interaksi sosial mirip pertunjukan drama, yang menampilkan peran. Dalam memainkan peran menggunakan bahasa verbal dan perilaku nonverbal dan mengenakan atribut tertentu. Penjelasan lain, Goffman, menjelaskan bahwa "panggung teater" dibagi menjadi wilayah depan" (front stage) yang merujuk peristiwa sosial bahwa individu bergaya menampilkan perannya dan wilayah belakang (back stage) yang merujuk tempat dan peristiwa yang memungkinkanmempersiapkan perannya di wilayah depan. Panggung depan dibagi menjadi dua yaitu; front pribadi (personal front) dan setting atas alat perlengkapan. Gambaran setting merupakan situasi fisik yang harus ada ketika aktor melakukan pertunjukan (Suneki dan Haryono, 2012).

Pendekatan dramaturgi ini menekankan pada konsepsi penggambaran "diri" dalam kehidupan sehari-hari seperti penjelasan berikut:

The "dramaturgical approach" was stressed that people's daily self-presentation was like stage acting. In other words, self-presentation was the present of self that individuals tended to perform intentionally and desired to be seen by others. The perception by others was to be controlled was called self-presentation (Leary and Kowalski, 1990)

Presentasi diri dalam gambaran "diri" Jamaah An-Nadzir dalam konteks interaksi sosial-simbolik sebagai "panggung teater" untuk menciptakan image optimal kepada dunia sosialnya. Asumsi Goffman bahwa ketika individu berinteraksi, menyajikan suatu gambaran diri yang diterima individu lain. Inilah yang disebut dengan "pengelolaan kesan“. Kesan dalam kehidupan sosial interpretasi makna berwujud perilaku. Bukan warisan budaya, sosialisasi, atau tatanan kelembagaan, atau perwujudan dari potensi psikologis dan biologis, melainkan pencapaian problematik interaksi manusia dan penuh dengan perubahan, kebaruan, dan kebingungan, dan secara sosial tetap 
berubah, arbiter, dan merupakan ramuan interaksi manusia (Jennifer, 2014).

Penjelasan tersebut mengindikasikan bahwa konsep peran dan konsep "diri" (dari teori interaksi simbolis) tampil dalam berinteraksi dengan individu lain dan diri sendiri yang berbeda dengan diri individu lain, dinamakan “identitas". Perilaku individu dalam suatu bentuk interaksi, dipengaruhi oleh harapan peran dan identitas dirinya, begitu juga perilaku pihak yang berinteraksi dengan dirinya.

Setiap individu memiliki identitas, baik secara personal maupun secara sosial. Ketika individu akan bergabung pada sebuah kelompok, pada dirinya melekat identitas personal dan ketika ia telah menjadi anggota sebuah kelompok, maka ia akan mengidentifikasi terhadap kelompoknya, yang menyebabkan identitas personalnya terabaikan; akan melebur atau tertutupi oleh identitas sosial.

Pendekatan dramaturgi tidak lepas dari pengaruh Cooley tentang the looking glass self, yang terdiri tiga komponen: Pertama: kita mengembangkan bagaimana kita tanpil bagai individu lain. Kedua: kita membayangkan bagaimana penilaian atas penampilannya. Ketiga: kita mengembangkan perasaan diri, seprti malu, bangga, sebagai akibat mengembangkan penilaian individu lain. Peran adalah suatu ekspektasi yang didefinisikan secara social yang dimainkan seseindividu. Fokusnya adalah "diri”, tersituasikan secara sosial dan simbolik berkembang untuk mengatur interaksi sosial bersifat simbolik dan spesifik. Lebih dikenal dengan istilah "pengelolaan kesan" (impression management) yaitu teknik-teknik yang digunakan aktor untuk memupuk kesan-kesan tertentu dalam situasi dan pencapaian tujuan tertentu (Suneki dan Haryono, 2012). Goffman mengasumsikan bahwa ketika individu berinteraksi, ingin menyajikan suatu gambaran diri yang akan diterima individu lain. Inilah yang disebut dengan "pengelolaan kesan" atau impression management, yaitu teknik yang digunakan aktor untuk memupuk kesan-kesan tertentu dalam situasi tertentu unutk mencapai tujuan tertentu (Rinawati, 2006: 149).

Pendekatan dramaturgi telah dikaji berbagai konsepsi hasil penelitian seperti dilakukan oleh Rini berjudul Dramaturgi Poligami, menggunakan pendekatan kualitatif, dalam mengungkapi perilaku komunikasi verbal dan nonverbal dari para suami yang melakukan poligami. Pengelolaan kesan di panggung depan atau front stage dan juga panggung belakang atau backstage dilakukan oleh suami yang berpoligami untuk memperoleh kesan setia, sayang istri, atau kesan positif lainnya di hadapan istri-istrinya melalui bahasa verbal maupun nonverbal (Rini, 2006). Perilaku komunikasi Jamaah An-Nadzir tampil menggunakan menggunakan atribut-atribut dakwah keagamaan untuk memproleh kesan dalam lingkungan sosialnya. Penelitian lainnya lainnya dilakukan Zubair (2013), fokus pada kajian Presentasi Diri Etnik Cina Bangka dalam Hubungan Bisnis dengan Etnik Melayu Bangka. Penelitian tersebut menggunakan pendekatan subyektif dengan perspektif interpretif. Hasil penelitian tersebut menemukan tampilan presentasi 
diri terdapat ketertiban interaksi yang muncul untuk memenuhi kebutuhan akan pemeliharaan keutuhan diri. Manusia adalah manipulator simbol, mendemontrasikan apa yang dikomunikasikan manusia kepada manusia lainnya ketika berinteraksi dalam situasi sehari-hari. Menurut pengamatan peneliti etnik Cina Bangka termasuk ahli menggunakan simbol dalam berkomunikasi dengan etnik (Zubair, 2013). Individu menggunakan simbol untuk mengekspresikan identitas diri.

Jamaah

An-Nadzir

dalam

menginterpretasikan 'diri' menggunakan simbol-simbol dalam upaya mempertahankan identitas melalui melalui pendekatan interaksi simbolik. Dengan kata lain, tampilan diri Jamaah An-Nadzir bertujuan untuk berperilaku dalam suatu panggung depan dan belakang kesan dalam sutu situasi drama teatrikal berdasarkan pada pendektan daramturgi. Penulis tertarik pada fokus penelitian bagaimana kelompok Jamaah An-Nadzir, dalam mengungkapkan dan merepresentasikan perilaku dirinya (self presentation) layaknya memainkan suatu panggung pertunjukan drama (pendekatan dramaturgi) bagi lingkungan sosialnya. Tampilan diri dalam suatu adegan sosial pada konteks panggung depan maupun panggung belakang di lingkungan sekitarnya. Tujuan penelitian ini mengungkapkan gambaran deskriktif perilaku pengeloaan kesan interaksi simbolik menampilkan presentasi diri kelompok Jamaah An-Nadzir di Kabupaten Gowa, meliputi: panggung depan (front stage) dan panggung belakang (back stage) dalam proses komunikasi kehidupan sosial simbolik sehari-hari.

\section{Metode Penelitian}

Metode penelitian digunakan adalah metode pendekatan kualitatif. Metode yang menekankan pada pemahaman mengenai masalah-masalah dalam kehidupan sosial berdasarkan kondisi realitas (natural setting) yang realistis, kompleks dan holistik. Seperti dijelaskan, Mason, J. (1996) yang dikutip Denzin dan Lincoln (2005) berikut ini:

"a process of inquiry with the goal of understanding a social or human problem from multiple perspectives; conducted in a natural setting with a goal of building a complex and holistic picture of the phenomenon of interest"

Penelitian kualitatif dipilih untuk lebih memahami kosntruksi realitas sosial dimana hubungan peneliti dan yang dikaji bersifat intim-situasional. Mencari jawaban dari pengalaman sosial yang diberi makna, bukan hubungan antar variabel dan konstan. Secara spesifik Lindlof menyebut penelitian kualitatif dalam ilmu komunikasi, sebagai paradigm interpretative atau perspektif interpretatif (Mulyana, 2001: 147-148).

Perspektif penelitian fenomenologi digunakan untuk sebagai suatu metode analisis data deskriptif serta introspektif mengenai kedalaman dari semua bentuk kesadaran dan pengalaman langsung. Tipe penelitian ini berusaha untuk mengungkap dan mempelajari serta memahami suatu fenomena beserta konteksnya yang khas dan unik yang dialami oleh individu hingga tataran 'keyakinan' individu yang bersangkutan. Dengan demikian dalam mempelajari dan memahaminya, haruslah berdasarkan sudut pandang, paradigma dan keyakinan langsung Jamaah An-Nadzir 
yang bersangkutan sebagai subjek yang mengalami langsung.

Selain metode, perspektif interaksi simbolik dan pendekatan dramaturgi, keduanya saling berkombinasi satu sama lainnya. Perspektif ini digunakan untuk mengeksplorasi interpretasi diri Jamaah An-Nadzir dalam berinteraksi sosial di lingkungan sekitarnya. Jamaah AnNadzir berinteraksi simbolik dalam proses komunikasi di lingkungan sekitarnya dengan presentasi diri pada panggung depan maupun belakang dalam menentukan representasi diri maupun kelompok. Lingkungan realitas sosial sebagai intersubjektif, saling berbagi, dan bernegosiasi. Layaknya suatu drama dimana diri sebagai aktor untuk menyesuaikan diri dengan tindakan individu lain.

Penggunaan perspektif dramaturgi ditampilkan diri Jamaah An-Nadzir, seperti dijelaskan, menurut Jennifer, (2014) bahwa:

A Goffmanian dramaturgical framework must consider the roles people adapt, interpretations of frame (or clues of this), regions (backstage or frontstage) and the type of audience that is present to understand meaning and the power dynamics of an interaction. It must understand all of these things to better comprehend what it is that is going on.

Pendekatan dramaturgi harus mempertimbangkan peran yang diadaptasi individu, interpretasi wilayah (belakang panggung atau depan panggung) dan jenis individu yang hadir untuk memahami makna dan dinamika interaksi untuk memahami hal lebih baik ke depannya.

Kerangka dramaturgi Goffmanian harus mempertimbangkan peran yang diadaptasi individu, interpretasi bingkai (atau petunjuk ini), wilayah (belakang panggung atau depan panggung) dan jenis audiens yang hadir untuk memahami makna dan dinamika kekuatan interaksi. Goffmania harus memahami semua hal ini untuk lebih memahami apa yang sedang terjadi.

Asumsi perspektif ini memberikan penjelasan bahwa bagaimana tampilan diri Jamaah An-Nadzir merefresentasikan dirinya (self presentation) layaknya memainkan suatu panggung pertunjukan drama bagi lingkungan sosialnya. Tampilan diri dalam suatu adegan sosial pada konteks panggung depan maupun panggung belakang di lingkungan sekitarnya.

Penelitian ini yang menjadi bahasan adalah self presentation Jamaah AnNadzir dalam menginterpretasikan 'diri' melalui pendekatan interaksi simbolik dan pendekatan dramaturgi. Lebih khusus lagi memaknai perilaku komunikasi simbolik diri individu jamaah An-Nadzir dalam suatu panggung depan, belakang dan pengelolaan kesan dalam sutu situasi drama teatrikal berdasarkan pada pendektan daramturgi.

Subjek penelitian merupakan komunitas kelompok Islam Jamaah AnNadzir di wilayah Kabupaten Gowa. Pemilihan subjek penelitian ini secara secara purposif didasarkan kriteria dan statusnya sebagai anggota kaum Muslim Jamaah An-Nadzir, sebanyak tujuh individu anggota. Mempertimbangkan secara representatif kesediaan mengeksplorasi dan mengartikulasikan pengalaman, maupun perilaku komunikasi kelompok.

Teknik pengumpulan data pada pendekatan ini meliputi: Pengamatan Langsung (participant observer), yaitu 
metode pengumpulan data penelitian dengan mengamati langsung rutinitas subjek penelitian dalam melakukan tampilan komunikasi. Wawancara mendalam (indepth interview), yaitu aktivitas wawancara mendalam yang dilakukan dengan cara tanya jawab secara langsung dengan informan yang diteliti serta metode dokumenter (documenter method), untuk memperoleh teori, konsep maupun keterangan melalui buku-buku, laporan hasil penelitian, jurnal, majalah, media online, dan sebagainya yang mempunyai relevansi dengan permasalahan penelitian.

Data yang terkumpul dianalisis menggunakan analisis data kualitatif. Analisis data kualitatif bersifat induktif berusaha memahami proses sosial yang berlangsung dan makna dari fakta-fakta nampak, dengan langkah-langkah sebagai berikut: pertama, reduksi data (data reduction), kedua, penyajian data (data display), dan ketiga, penarikan kesimpulan (conclusion drawing and verification).

\section{Hasil Penelitian dan Pembahasan}

Jamaah An-Nadzir merupakan komunitas gerakan dakwah bagi agama Islam. Jamaah ini muncul sejak tahun 1998 berpusat di pinggiran utara Danau Mawang, Kelurahan Romanglompoa, Kecamatan Bontomarannu, Kabupaten Gowa. Keunikan budaya dan komunikasi menjadi identitas komunitas ini. Gerakan dakwah seluruh pengikutnya secara konsisten melalui simbol-simbol yang dikenakan sehari-hari dan hal itu yakini sebagai Sunnah Nabi, dalam melakukan kegiatan gerakan dakwah.
Gerakan dakwah Jamaah An-Nadzir ini dikenal dengan istilah "bil al-hal", yakni dakwah dengan perbuatan nyata atau aktivitas yang dilakukan dalam bentuk tindakan amal nyata, berdasarkan pada tuntunan Nabi Muhammmad SAW. Gerakan dakwah Jamaah An-Nadzir ini merupakan bagian dari gerakan sosial yang dinamakan gerakan sosial keagamaan. Komunitas Jamaah An-Nadzir melakukan kegiatan sosialkeagamaan (gerakan dakwah) melakukan berbagai strategi dalam melakukan seluruh aktivitasnya.

Gerakan dakwa Jamaah An-Nadzir memiliki perbedaan dengan gerakan Islam lainnya. Perbedaan yang mencolok adalah pada simbol-simbolkeagamaanyangmenjadi atribut dan identitas kelompoknya. Ciri khas visual mengenakan tampilan sehari-hari mengenakan simbol-simbol khusus sebagai pembeda dengan komunitas Islam atau komunitas gerakan dakwah lainnya. Jamaah An-Nadzir memahami bahwa citra dirinya di depan masyarakat terbentuk semata-mata karena tampilan dirinya.

Para artis pun sangat memahami bahwa citra dirinya didepan publikterbentuksematamata justru karena kehidupan pribadinya yang terekspos di media massa. Artis sangat menjaga citra dirinya yang sudah terbentuk di publik. Upaya artis dalam mempersiapkan citra diri yang ingin dibentuknya di hadapan wartawan. Artis sangat memahami, jika persiapan sebelum bertemu wartawan dan melakukan wawancara penting untuk dilakukan, misalnya, tampil rapi dan merias diri terlebih dahulu sebelum bertemu wartawan; menenangkan diri dan berusaha 
berada dalam kondisi emosi yang stabil; dan berdiskusi dengan manajemen untuk menampilkan citra diri yang positif di hadapan wartawan. (Pattipeilohy, 2015)

Jamaah An-Nadzir khas tampil sebagai individu Muslim taat, peniru dan mencontohkan Sunnah Nabi Muhammad SAW. Bukan hanya ungkapan verbal namun diaplikasikan dalam bentuk tampilan simbol-simbol diri sebagai individu "aktor", beridentitas muslim yang taat pada ajaranajaran Islam dikenakan dalam setiap aktivitas sosialnya. Atribut simbol-simbol diri yang identik dengan simbol-simbol Islam, ditampilkan dalam suatu konteks sosial. Seperti, memakai pakaian warna hitam, mengenakan surban, mewarnai dan memanjangkan janggut dan rambut berwarna khas coklat.

Setiap anggota Jamaah An Nazir ini hadir layaknya sebagai individuaktor, tampil dalam suatu panggung "teater sosial" dalam suatu interaksi sosial. Penjelasan Goffman (1959) dalam perspektif dramaturgi sebagai metafora utama presentasi diri dalam interaksi sosial. Anggota Jamaah An-Nadzir sebagai pemain, memainkan diri sebagai aktor di panggung teater. Goffman membuat perbedaan antara panggung belakang dan panggung depan. Menampilkan batas antara panggung pribadi, dan panggung kehidupan sosial/publik dalam mempresentasikan diri dalam lingkungan sosial.

Presentasi diri Jamaah An-Nadzir hadir dalam suatu interaksi dengan individu lain, bentuk pengiriman dan penerimaan pesan dalam suatu presentasi diri dalam pertunjukan sosial. Panggung "teater" sosial menghadirkan aktor di panggung belakang terhubung ke dunia pribadi di mana "penonton" tidak hadir dan "pemain dapat bersantai, jauh dari panggung depan, dan melangkah keluar dari karakter". Tampilan presentasi diri anggota Jamaah An-Nadzir tentu tidak hanya membutuhkan simbolsimbol atribut pendukung, tetapi juga perlu tetap mempertahankan standar perilaku dan penampilan melalui pengelolaan kesan (impression management) sebagai bagian dari komunitas.

\section{Panggung Depan Jamaah An-Nadzir}

Presentasi diri Jamaah An-Nadzir tampil sebagai "aktor" berusaha untuk menggabungkan kartakteristik personal dan mengembangkan perilaku-perilaku yang mendukung perannya. Aktor dalam kehidupan pertunjukan 'teater' di kehidupan sosial dan harus mempersiapkan kelengkapan pertunjukan "diri”, antara lain, kostum, penggunaan kata, dan gerak nonverbal.

Penggunaan perlengkapan pertunjukan "diri" dalam rangka meluluskan capaian tujuan, yaitu untuk meningkatkan kesan pada lawan berinteraksi. Pendekatan dramatugi menjelaskan bahwa interaksi sosial dimaknai sama dengan pertunjukan teater di atas panggung.

Presentasi diri Jamaah An-Nadzir dalam panggung depan merupakan ranah publik dan sosial. Pelibatan dalam pengelolaan kesan dan mendapatkan kontrol atas ekspresi citra positif, presentasi diri melalui penggunaan atribut-atribut pelengkap yang digunakan, seperti sorban, jubah, janggot dan rambut yang dibiarkan panjang dalam dalam 
menyajikan gambaran ideal kelompoknya. Pengelolaan kesan dalam persentase diri Jamaah An-Nadzir dalam kehidupan panggung depan untuk menekankan aspek personaliti dengan mengenakan jubah, surban, jenggot dan rambut dibiarkan panjang menyampaikan image terbaik untuk mempertahankan kesan yang baik dari individu lain. Upaya mempertahankan tampilan dirinya, bentuk, model, dan simbol pakaian An-Nadzir merupakan simbol kesan pakaian ummat Islam, taat melaksanakan Sunnah Rasullulah. Hasil wawancara, Ustad Lukman (hasil wawancara, 6 Juni 2018), mengatakan bahwa:

"Sorban dikepala, rambut pirang, pakaian jubah, dan janggut dibiarkan panjang berwarna coklat adalah milik Rasulullah sebagai wujud pengimplementasian akan penyaksian Muhammad sebagai utusan-Nya, bukanlah milik An-Nadzir, melainkan milik Muhammad SAW"

Keterlibatannya dalam suatu interaksi sosial dalam suatu panggung depan untuk mengekplorasi peran sebagai aktor dalam suatu "panggung teater sosial" berharap peran ini membuat dirinya muncul secara positif bagi individu lain. Berusaha untuk "memanipulasi” penonton dan tampil secara refleks dalam konteks pengeloaan kesan.

Pengelolaan kesan dalam pemciptaan aktivitas sosial berupa gerakan dakwah, melalui tampilan perilaku dalam suatu konteks interaksi soail sebagai bagian kegiatan dakwah. Tampilan perilaku diri ditentukan sendiri bersifat aktif, refleklektif, dan kreatif bagi individu lain kadang sulit diramalkan. Presentasi diri wujud perilaku yang ditampilkan anggota komunitas ini, memiliki pesan dan kesan yang dapat dipahami baik.

Presentasi diri panggung depan merupakan bagian dari pertunjukkan kelompok Jamaah An-Nadzir yang secara reguler berfungsi untuk menunjukkan penampilannya untuk mendefinisikan situasi untuk siapa saja yang mengamati pertunjukkan tersebut. Presentasi diri panggung depan Jamaah An-Nadzir mengkombinasikan ragam atribut; mengenakan surban di kepala, jubah, rambut

Tabel 1. Presentasi Diri Panggung Depan Kelompok Jamaah An-Nadzir di Kabupaten Gowa

\begin{tabular}{|c|c|c|}
\hline $\begin{array}{l}\text { Presentasi Diri Panggung } \\
\text { Depan Jamaah An-Nadzir }\end{array}$ & Pengelolaan Kesan & Makna Presentasi Diri \\
\hline $\begin{array}{l}\text { Mengenakan Surban di } \\
\text { kepala }\end{array}$ & $\begin{array}{l}\text { Menciptakan kesan pendakwah } \\
\text { dan Sunnah Nabi Muhammad SAW } \\
\text { dan pembeda manusia serta jenjang } \\
\text { keilmuan }\end{array}$ & $\begin{array}{l}\text { Diri dalam kelompok sebagai Pendakwah } \\
\text { dan Melaksanakan Sunnah Nabi }\end{array}$ \\
\hline Memakai Jubah Hitam & $\begin{array}{l}\text { Menciptakan kesan pendakwah dan } \\
\text { menghidupkan Sunnah Nabi } \\
\text { Muhammad SAW }\end{array}$ & $\begin{array}{l}\text { Diri dalam kelompok Sebagai Pendakwah } \\
\text { dan Menghidupkan Sunnah Rasul }\end{array}$ \\
\hline $\begin{array}{l}\text { Rambut warna Coklat/ } \\
\text { pirang dibiarkan panjang }\end{array}$ & $\begin{array}{l}\text { Menciptakan kesan pendakwah, } \\
\text { tuntunan dan perintah Nabi } \\
\text { Muhammad SWT kepada sahabat } \\
\text { dan usia muda }\end{array}$ & $\begin{array}{l}\text { Diri dalam kelompok Sebagai pendakwah } \\
\text { dan Menjalankan Perintah Nabi Muhammad } \\
\text { AS }\end{array}$ \\
\hline $\begin{array}{l}\text { Jenggot warna Coklat/ } \\
\text { pirang }\end{array}$ & $\begin{array}{l}\text { Menciptakan kesan pendakwah } \\
\text { sebagai pengikut dan pencinta } \\
\text { Rasullulah SAW dan mempertegas } \\
\text { identitas }\end{array}$ & $\begin{array}{l}\text { Diri dalam kelompok Pendakwah dan } \\
\text { Pencinta Nabi Muhammad AS }\end{array}$ \\
\hline
\end{tabular}

Sumber: Hasil Olahan Data Primer, 2018 
dan jenggot dibiarkan panjang diwarnai coklat/pirang dalam suatu tampilan formal dalam suatu identitas diri dalam konteks interasksi sosial antar anggota kelompok maupun masyarakat. Pendekatan dramaturgi Jamaah An-Nadzir berperan sebagai aktor dalam suatu interaksi sosial formal sebagai bentuk aktivitas gerakan dakwah. Pengelolaan kesan dilakukan dengan tujuan menciptakan kesan dakwah, menghidupkan Sunnah nabi, tuntunan nabi, dan sunnah nabi Muhammad SAW. Pengaturan mengenai diri yang berkaitan peran dengan segala atribut yang diatur untuk memenuhi suatu standard diri yang dikonsepkan.

Presentasi diri merupakan peran ditampilkan dalam berinteraksi dan berbeda dengan individu lain, untuk membangun harapan-harapan sosial dan menguatkan identitas kelompok. Pertimbangan bahwa ketika memiliki identitas, baik secara personal maupun secara kelompok. Memudahkan dalam mengidentifikasi diri pada kelompoknya, presentasi diri dalam panggung depan menyebabkan identitas diri terabaikan, kemudian melebur atau tertutupi oleh identitas sosial.

Presentasi diri Jamaah An-Nadzir dalam Panggung depan menampilkan dirinya di depan publik agar tercapainya citra diri yang diinginkan. Presentasi diri dalam suatu desain aktivitas dakwah secara komprehensif yang memadukan dakwah bil al-lisan (komunikasi verbal) dan bi al-hal (komunikasi nonverbal) melaui perbuatan nyata pada seluruh aspek kehidupan pelaku dakwah sehingga dakwah dapat memberi kontribusi besar bagi perubahan sosial
Presentasi diri dalam panggung depan ini dapat berubah melalui suatu proses perilaku pengelolaan kesan. Hal ini diakukan untuk mempresentasikan diri diluar ruang kelompok atau publik (panggung belakang). Goffman mengemukakan bahwa pengelolaan kesan sebagai kebutuhan individu dalam mempresentasikan dirinya sebagai seindividu yang bisa diterima oleh individu lain. Diri sebagai penampil (self as performer), bukan semata-mata sebuah produk sosial, tetapi juga memiliki dasar motivasi. Individu menata kesan miliknya ketika berharap untuk diterima sebagai individu yang memiliki citra diri disukai oleh individu-individu. Pengelolaan kesan digunakan dalamkonteks untukmendapatkan pujian atas pertunjukan dan mencari umpanbalik. Perspektif pengelolaan kesan (the impression management perspective) menjelaskan bahwa individu memanipulasi dan mencoba mengendalikan kesan, membentuknya perilaku yang sesuai dengan situasi. Perilaku semacam itu dirancang oleh aktor untuk menetapkan tampilan presentasi diri yang diinginkan dan diterima individu lainnya (Efrat Tseeion, 1992).

Presentasi diri melalui pengelolaan kesan panggung depan Jamaah AnNadzir merupakan tampilan diri dalam suatu tujuan gerakan dakwah. Gerakan dakwah untuk perubahan pada masyarakat dari satu kondisi menuju kondisi yang lebih baik. Konsekuensi logisnya metode dakwah kedepan tidak hanya pada gerakan dakwah bi al-lisan (verbal) dan tetapi juga memikirkan pola gerakan dakwah bi-al-hal (non-verbal). Dakwah bi al-hal (non-verbal) 
adalah gerakan dakwah dengan perbuatan nyata atau aktifitas dakwah yang dilakukan dalam bentuk tindakan amal nyata. Dakwah tidak sekedar menyampaikan gagasangagasan keagamaan tetapi juga bersifat solusi dari semua permasalahan ummat manusia termasuk ekonomi, politik dan sosial dan dilakukan dengan berbagai metode termasuk melalui simbol, atribut dan lain sebagainya. Dalam terminologi Islam yang dikenal dengan dakwah bil alhal, yakni dakwah dengan perbuatan nyata atau aktivitas yang dilakukan dalam bentuk tindakan amal nyata. Simbol dan identitas dalam komunitas ditampilkan oleh seluruh pengikutnya secara konsisten dan hal itu yakini sebagai Sunnah Nabi. Beberapa simbol yang telah menjadi identitasnya adalah cara berpakaian, memelihara janggut dan rambut panjang yang dipirangkan.

Setiap aktivitas gerakan dakwah harus senantiasa mempertimbangkan kondisi sosial yang mengitarinya, sehingga aktivitas gerakan dakwah tersebut memiliki relevansi dengan realitas sosial yang ada. Individu tidak dapat berharap banyak dalam memelajari perubahan sosial sebelum memahami secara memadai struktur sosial karena masyarakat merupakan suatu sistem sosial yang terdiri atas bagian-bagian, atau elemen yang saling berkaitan dan menyatu dalam keseimbangan. Asumsi dasar teori ini adalah bahwa setiap struktur dalam sistem sosial, fungsional terhadap yang lain.

Pandangan kelompok Jamaah
An-Nadzir, cara ibadah yang mampu
menyelamatkan manusia adalah cara ibadah
yang telah diajarkan dan dicontohkan oleh

Rasulullah SAW. Landasan mengikuti Sunnah Nabi, An-Nadzir memiliki konsep ibadah yang berbeda dengan mayoritas ummat Islam pada umumnya. Baik dalam cara penentuan waktu sholat dan tata cara sholat, penentuan hari raya Idul Fitri serta dalam salah satu lafadz Adzan.

Gerakan dakwah yang dilakukan Jamaah An-Nadzir secara partisipatif merupakan bentuk presentase diri yang bersifat interaktif karena mampu menyesuaikan pesan-pesan dakwah dengan kondisi individual dan sosial obyek dakwah. Proses interaksi antara cita ideal dakwah dengan kecenderungan yang dimiliki oleh obyek dakwah. Perbedaan karakter dan problematika yang dimiliki oleh obyek dakwah membuat rencana dan pelaksanaan dakwah juga harus berbeda dari segi metode dan prioritas materimateri dakwah, sebab metode dakwah menyangkut bagaimana seharusnya dakwah itu dilaksanakan.

\section{Panggung Belakang Jamaah An-Nadzir}

Presentasi diri ketika berada di panggung belakang (back stage), ketika Jamaah An-Nadzir merasa nyaman dengan diri sendiri dan berada di satu lingkungan dengan individu-individu yang dianggap akrab dan dekat seperti ketika berada dirumah atau ketika para anggota Jamaah ini bertemu dengan individu lain. Panggung belakang merupakan keadaan dimana seindividu berada di belakang panggung dengan kondisi tidak ada penonton, sehingga dapat dipastikan seindividu tersebut dapat berperilaku bebas tanpa mempedulikan sikap/peran dalam sandiwara berikutnya. Individu anggota Jamaah An-Nadzir tampil 
secara sederhana tanpa atribut dikenakan saat tampil sebagai individu pendakwah dengan atribut tampilan diri sesuai dengan Sunnah Nabi.

Presentasi diri panggung belakang tampil dengan atribut simbolik berupa identitas diri Jamaah An-Nadzir mengenakan kaos dan celana biasa (bukan jubah) dan mengenakan tutup kepala bukan berupa sorban. Hasil wawancara Dayat (hasil wawancara, 6 Juni 2018), mengatakan bahwa:

"tampilan kami berbeda jika di rumah maupun dikeseharian, jika dirunah bersama keluarga lebih santai, cuman kaos dan celana pendek, demikian juga ketika ke sawah sebagai petani, biasa tampil seperti biasa, mengenakan kaos, celana pendek, bawa cangkul hingga topi yang biasa kami gunakan...pakaian yang penting bersih".

Pengelolaan kesan ketika berinteraksi untuk menyajikan gambaran diri sebagai seindividu yang berbeda ketika dalam panggung belakang bersama keluarga maupun komunitasnya untuk memberikan informasi dan tetap diterima sebagai individu diri yang tampil berdasarkan konteks lingkungan sosial, seperti tertera pada tabel 2:

Tampilan presentasi diri Jamaah AnNadzir pada panggung belakang merupakan upaya individu menginginkan kehidupan sosial diterima oleh pihak lain apa adanya karena itu beradaptasi dengan rutinitas yang sudah ditetapkan sebagai suatu peran sosial lainnya. Penciptaan kesan diri sebagai pribadi sederhana dan penciptaan kesan diri sebagai diri pribadi sederhana dan akrab dalam setting lingkungan keluarga dan tempat kerja. Misalnya, mengenaikan kaos, tutup kepala bukan sorban/topi untuk menciptakan kesan pribadi sederhana dan akrab bersama keluarga, teman atau tetangga sekitar lingkungan tempat tinggal.

Konteks panggung belakang, individu Jamaah An-Nadzir menggunakan teknik pengelolaan kesan untuk bertindak dengan cara yang mendukung keanggotaan atau kesatuannya kelompok lainnya, yang lebih kekeluargaan, akrab dan tanpa batas. Layaknya pada saat di sawah, memakai kaos oblong, celana pendek 3/4, serta mengenakan topi. Anggota Jamaah AnNadzir memilih untuk menggambarkan diri atau tidak menggunakan stereotip yang mementingkan dirinya. Memberi kesan kepada individu lainnya dari penggunaan simbol atribut, penampilan, dan kebiasaan sama dengan individu lain. Tujuannya agar individu lain memandang dirinya sebagai individu yang sederhana, dan sama dalam

Tabel 2. Presentasi Diri Panggung Depan Kelompok Jamaah An-Nadzir di Kabupaten Gowa

\begin{tabular}{|c|c|c|}
\hline $\begin{array}{c}\text { Presentasi Diri } \\
\text { Panggung Belakang } \\
\text { Jamaah An-Nadzir }\end{array}$ & Pengelolaan Kesan & Makna Presentasi Diri \\
\hline $\begin{array}{l}\text { Kaos dan celana biasa } \\
\text { (bukan Jubah) }\end{array}$ & $\begin{array}{l}\text { Penciptaan kesan diri sebagai } \\
\text { pribadi sederhana }\end{array}$ & Diri sebagai Pribadi Sederhana \\
\hline $\begin{array}{l}\text { Tutup kepala bukan } \\
\text { Sorban (topi) }\end{array}$ & $\begin{array}{l}\text { Pencipatakan kesan diri } \\
\text { sebagai diri pribadi sederhana } \\
\text { dan akrab }\end{array}$ & $\begin{array}{l}\text { Diri sebagai Pribadi Sederhana dan } \\
\text { akrab }\end{array}$ \\
\hline
\end{tabular}

Sumber: Hasil Olahan Data Primer, 2018 
profesi petani dalam kehidupan sehari-hari.

Pengelolaan kesan diri Jamaah AnNadzir dalam wujud presentasi diri dalam panggung belakang merupakan suatu ungkapan diri yang ditunjukkan dalam bentuk lain agar membuat individu lain menyukai kesannya atau sebuah kesan yang cocok untuk suatu rencana tertentu dalam suasana pertemanan. Proses ini dikenal bahwa presentasi diri berhubungan dengan usaha individu untuk mengontrol image individu, dirancang untuk diri individu sendiri untuk menyesuaikan diri dalam melakukan interaksi sosial.

Diri Jamaah An-Nadzir bebas menjadi jati dirinya sendiri tanpa harus memainkan peran. Saat dimana tidak perlu lagi menutupi surbannya. Di lingkungan tersebut yang dinilai dapat memberikan kenyamanan untuk bersosialisasi dengan tujuan untuk mencapai suatu kebutuhan psikologis seperti diterima, dihargai, dan mendapat kasih sayang.

Layaknya seperti seorang aktor panggung, aktor sosial membawakan peran, mengasumsikan karakter, dan bermain melalui atribut-atribut sederhana layaknya individuketikaterlibatdalaminteraksidengan anggota keluarga. Presentasi diri Jamaah An-Nadzir melalui merepresentasikan dirinya sebagai manipulasi atau tidak seperti dirinya yang sesungguhnya. Suatu peran dalam pembentukan kesan yang disengaja dan dilakukan secara sadar dibentuk agar tercapai suatu tujuan yang sudah direncanakan. Dalam pengelolaan kesan ini, anggota kelomok Jamaah An-Nadzir mengatakan hal positif tentang diri atau mengatakan tentang hal yang positif tentang dirinya supaya terlihat kesederhanaannya, keakraban, dan humoris.

Secara visual jamaah An-Nadzir menampillkan diri dengan simbol-simbol yang berbeda dari pemahaman keagamaan berbasis literalis yang bertumpu pada pahaman tekstual terhadap Al-Qur'an dan hadist. Seluruh ibadah dan kegiatan harus berdasarkan Sunnah Nabi Muhammad SAW. Jamaah An-Nadzir sebagai komunitas Islam, walaupun sangat literatif dalam pandangan keagamaannya, tetapi sangat luwes dalam interaksi sosialnya. Bahkan, aktivitas kesehariannya telah melebur dengan warga setempat. Jamaah An-Nadzir sangat aktif dalam usaha-usaha ekonomi kerakyatan, gotong royong, hadir dalam acara keagamaan dan pernikahan bersama masyarakat setempat serta silaturahmi dengan pemerintah setempat, dalam kehidupan sehari-harinya.

Jamaah An-Nadzir dalam membangun keintiman dan kepercayaan masyarakat setempat. Peleburan jamaah An-Nadzir dengan masyarakat setempat dalam bingkai kejujuran, amanah telah melahirkan kepercayaan masyarakat untuk membangun kerja sama dalam bidang pertanian dalam bentuk bagi hasil dari tanah masyrakat yang dikelolah jamaah An-Nadzir.

Refresentasi diri dalam panggung belakang Jamaah An-Nadzir banyak fenomena sosial terungkap, bahwa pelaku dakwah baik dalam dakwah individu maupun kelompok tidak memperlihatkan keselarasan perilaku dan ucapannya, antara pesan verbal dan nonverbal. Hakikat pandangan An-Nadzir, dalam berinteraksi 
sosial dengan masyarakat terdapat unsur dakwah didalamnya. Dakwah tidak selalu harus di atas mimbar ataukah keluar ke daerah pelosok selama beberapa hari untuk tabliq. An-Nadzir basis utama ajarannya berpengang teguh pada Al-Qur'an dan hadist, akan tetapi sangat terbuka dalam mengakomodir dinamika sosial yang berhubungan dengan masalah-masalah muamalah. Hal ini sebagaimana di jelaskan dalam Al-Qur'an surah Al- Imran: 103:

"Dan berpengang teguh kalian pada tali Allah". Semua mufassir sepakat bahwa yang di maksud tali Allah adalah Al-Qur'an dan Hadist Nabi Muhammad SAW.

Perspektif dramaturgi yang diperhitungkan merupakan konsep menyeluruh menghayati peran sehingga dapat memberikan keuntungan sesuai yang diinginkan. Konteks dari perilaku Jamaah An-Nadzir ini bertujuan untuk mencapai tujuan interaksi sosial. Dramaturgi memahami bahwa dalam interaksi antar manusia ada "kesepakatan" perilaku yang disetujui yang dapat mengantarkan kepada tujuan akhir dari maksud interaksi sosial tersebut. Bermain peran aktor dalam setiap panggung merupakan salah satu alat yang dapat mengacu kepada tercapainya kesepakatan tersebut. Peneliti Winter K (2014) menyatakan hasil penelitian tampilan presentase diri remaja di media facebook menggunakan taktik, seperti deskripsi diri, pernyataan sikap, perilaku nonverbal, dan kepatuhan. Taktik presentase diri Jamaah An-Nadzir dalam bentuk pesan nonverbal tampil bertujuan untuk menyampaikan kesan atau peran dilakoni kepada individu lain.
Jamaah kelompok An-Nadzir dalam menjalani proses kehidupan baik individu, kelompok maupun dalam bermasyarakat berpengan pada prinsip nilai-nilai ajaran Islam. Dalam interaksi sosialnya mengedepankan gotong-royong, kejujuran, ramah tamah. Masyarakat telah menyaksikan nilai-nilai tersebut dalam komunitas AnNadzir dan sangat memberikan apresiasi serta kepercayaan terhadap kelompok tersebut.

\section{Simpulan}

Perilaku pengeloaan kesan tampilan presentasi diri kelompok Jamaah An-Nadzir di Kabupaten Gowa dalam suatu pendekatan dramaturgi dalam proses komunikasi kehidupan sosial sehari-hari. Tampil dalam perspektif dramaturgi, panggung teatrikal sebagai "aktor" berusaha untuk menggabungkan karakteristik personal dan mengembangkan perilaku-perilaku yang mendukung perannya. Perilaku pengelolaan kesan untuk mendapatkan ekspresi citra positif, presentasi diri melalui pengelolaan kesan dalam Persentasi diri Jamaah AnNadzir dalam kehidupan panggung depan untuk menekankan aspek personaliti dengan mengenakan jubah, surban, jenggot dan rambut dibiarkan panjang menyampaikan image terbaik untuk mempertahankan kesan yang baik dari individu lain.

Konteksnya perilaku pengelolaan kesan untuk panggung belakang, tampilan presentasi diri bertindak dengan cara yang mendukung keanggotaan atau kesatuan kelompok lainnya, yang lebih kekeluargaan, akrab dan tanpa batas. Layaknya pada saat di sawah, mengenaikan kaos oblong, celana 
pendek 3/4, serta mengenaikan topi. Jamaah An-Nadzir merasa nyaman dengan diri sendiri dan berada di satu lingkungan dengan individu-individu yang dianggap akrab dan dekat seperti ketika berada dirumah atau ketika para anggota Jamaah ini bertemu dengan individu lain.

Diharapkan tampilan presentasi diri individu khas dalam masyarakat memberi kesan yang baik untuk mencapai tujuan berkomunikasi. Untuk itu diperlukan peran individu (back stage and front stage) yang tepat dan sesuai situasi sosial individu. Tidak terjadi kontradisksi dengan suatu yang nyata (real) dalam suatu lingkungan dan konteks interaksi sosial sehingga sesuai dengan kenyataan yang ada dalam kehidupan sosial. Penggunaan pendekatan dramaturgi telah bermanfaat dalam mengeksplorasi interaksi sosial dalam proses komunikasi melalui tampilan presentase diri kelompok Jamah An-Nadzir sebagai upaya untuk memupuk kesan dakwah yang telah digunakan untuk menyesuaikan panggung depan atau untuk menumbuhkan citra yang lebih baik di depan individu lain sebagai panggung belakang.

\section{Daftar Pustaka}

Benedictus A.S. (2010). Konstruksi Diri dan Pengelolaan Kesan pada Ruang Riil dan Ruang Virtual. Jurnal Aspikom Volume 1, Nomor 1, Juli 2010: 1-124

Denzin, Norman K. \& Lincoln, Yvonna,S. (2005). Handbook of Qualitative Reserach: Sage Publication

Efrat Tseeion.(1992). SelfPresentationthrough Appearance: A Manipulative vs. a Dramaturgical Approach, Jurnal Symbolic Interaction Volume 15, Number 4, 1992; 502
Haliemah, Noor dan Kertamukti Rama, (2017). Interaksi Simbolis Masyarakat Dalam Memaknai Kesenian Jathilan. Jurnal Aspikom Volume 3, Nomor 3, Juli 2017: 499

Jennifer Dell, 2014. Goffman's Dramaturgy: A Case Study Analysis for Potential Inclusion in Communication Theory Studies (tesis tidak diterbitkan)

Juliadi, (2016). Analisis Simiotika Komunikasi Non Verbal Jamaah-An Nazir Di Kabupaten Gowa (tesis, tidak diterbitkan).

Leary, M. R. and Kowalski, R. M., (1990). Impression Management: A literature Review and Two-factor Model. Psychological Bulletin, No. 107, page; 34-47.

Mulyana, Deddy, (2001), Metodologi Penelitian Kualitatif Paradigma Baru Ilmu Komunikasi dan Ilmu Sosial Lainnya, Bandung: PT Remadja Rosdakarya

Pattipeilohy E Meilany (2015), Citra Diri dan Popularitas Artis. Jurnal Kajian Komunikasi (Akreditasi Dikti), Volume 3, No. 1

Rinawati, Rini (2006). Dramaturgi Polgami. Jurnal MediaTor, Vol. 7. Nomor: 1, Juni 2006

Suneki, Sri \& Haryono, (2012). Paradigma Teori Dramaturgi Terhadap Kehidupan Sosial. Jurnal Ilmiah Avis, Volume II, No 2.

Santoso, Edi. Dkk. (2012). Teori Komunikasi. Yogyakarta: Graha Ilmu.

Umiarso \& Elbadiansyah. (2014). Interaksionisme Simbolik dari Era Klasik Hingga Modern. Jakarta : Rajawali Pers.

Vohs, K.D., Baumeister, R.F., and Ciarocco, N.J., (2005). Self-Regulation and SelfPresentation: Regulatory Resource 
Depletion Impairs Impression Management and Effortful Self-

Presentation Depletes Regulatory

Resources. Journal of Personality and Social Psychology,

Winter K.W. (2014). Faces on Facebook: A Study of Self-Presentation and Social
Support on Facebook. USA. DiscoverySS Student E-Journal 184 Vol. 1

Zubair, Agustina, (2013). Presentasi Diri Etnik Cina Bangka dalam Hubungan Bisnis dengan Etnik Melayu Bangka. Jurnal Komunikasi, Volume 1, Nomor 6, Januari 2013 